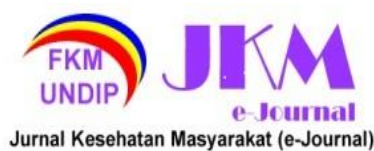

JURNAL KESEHATAN MASYARAKAT (e-Journal)

Volume 10, Nomor 1, Januari 2022

ISSN: 2715-5617 / e-ISSN: 2356-3346

http://ejournal3.undip.ac.id/index.php/jkm

\title{
ANALISIS MANAJEMEN LOGISTIK OBAT DI GUDANG FARMASI PUSKESMAS KARANGMALANG KOTA SEMARANG
}

\author{
Novisa Hamdani ${ }^{1}{ }^{*}$, Fitri Indrawati ${ }^{1}$ \\ ${ }^{1}$ Ilmu Kesehatan Masyarakat Fakultas Ilmu Keolahragaan Universitas Negeri Semarang \\ *Corresponding author : novisahamdani7499@gmail.com
}

\begin{abstract}
The highest increase of damaged or expired drugs at Karangmalang Healthcare Center in 2020 was 48,060 drugs, caused a stock accumulation. As of January to March 2021, it was reported that 2,739 drugs were damaged or expired and out of stock during the pandemic. Stock outs and stagnant drug could result in drug logistics management not going well. The purpose of this study was to determine the logistics management of drugs in the pharmacy warehouse of Karangmalang Pimary Healthcare Center Semarang City. Qualitative study was applied in this research. The informant is an employee of the Karangmalang Primary Healthcare Center Semarang City, with purposive sampling. Data is processed and presented in narrartive form. From the input aspect, it was found that in terms of funds, it was quite good, but for drug management staff there had never been any training, inadequate facilities and infrastructure and incomplete prosecures. Aspects of the process for planning and procurement often occur vacancies, inadequate drug storage because it had a small building size, as well as recording and report in there were still missed drugs or even excess stock which result in a lot of damaged/expired drugs. The output aspect of drug availability is currently in accordance with the needs, but its implementation had not been effective and efficient because there were still vacancies, expired/damaged, and missed drugs.Suggenstions for the Karangmalang Primary Healthcare is to carry out routine evaluations of drug management and renovate inadequate drug storage warehouse.
\end{abstract}

Keywords : Drug Logistsics Management, Pharmacy Warehouse, Primary Healthcare

\section{PENDAHULUAN}

Manajemen obat merupakan rangkaian kegiatan terpenting yang mendapatkan alokasi dana pemerintah sebesar $40-50 \%$ dari dana alokasi pembangunan kesehatan yang menyangkut aspek perencanaan, pengadaan, penyimpanan, dan pendistribusian obat yang dikelola secara optimal untuk menjamin tercapainya jumlah dan jenis perbekalan farmasi dan alat kesehatan ${ }^{(1)}$.

Berdasarkan laporan kinerja Direktorat Jenderal Kefarmasian dan Alat Kesehatan tingkat ketersediaan obat essensial di kabupaten/kota tahun 2020 sebesar 83,75\%. Namun di Provinsi Jawa Tengah capaian persentase kabupaten/kota dengan ketersediaan obat essensial masih di bawah target nasional sebesar $71,43 \%$ yang dimana hanya $71,43 \%$ kabupaten/kotanya yang tersedia dari target $85 \%$ obat essensial (40 item obat indikator). Dengan adanya permasalahan COVID-19 di Indonesia dapat memberi dampak bagi Dinas Kesehatan Provinsi dan Kabupaten/Kota sehingga tidak semua provinsi dan kabupaten/kota melakukan pemantauan, pencatatan dan pelaporan indikator terkait ketersediaan obat. Serta beberapa item obat indikator masih terdapat di Dinas Kesehatan Provinsi belum terdistribusi merata ke semua kabupaten/kota ${ }^{(2)}$.

Puskesmas Karangmalang merupakan unit pelaksana teknis Dinas Kesehatan Kota Semarang yang bertanggung jawab meneyelenggarakan pembangunan kesehatan di wilayah kerja sebagai
Unit Pelaksana Teknis Daerah Kota Semarang. Oleh karena itu diketahui bahwa manajemen logistik di gudang farmasi Pukesmas Karangmalang Kota Semarang setiap tahun terdapat obat rusak atau kadaluwarsa. Dalam tiga tahun terakhir pelaporan obat rusak atau kadaluwarsa tetap ditemukan, pada tahun 2018 terdapat 33.959 obat rusak atau kadaluwarsa, di tahun 2019 terdapat 18.038 obat rusak atau kadaluwarsa, dan di tahun 2020 terdapat 48.060 obat rusak atau kadaluwarsa. Pada Tahun 2021 sudah terdapat juga obat rusak atau kadaluwarsa per bulan Januari sampai dengan Maret sebanyak 2.739 obat rusak atau kadaluwarsa. Kenaikan Jumlah obat rusak atau kadaluwarsa setiap tahunnya belum dapat diminimalisir sehingga terjadi penumpukan stok obat. Kekosongan obat juga terjadi akibat meningkatnya kasus Covid-19 di wilayah Puskesmas Karangmalang dan waktu tunggu yang lama untuk mendapatkan kiriman obat dari pusat ataupun distributor. Selain itu gudang tempat penyimpanan obat di Farmasi Puskesmas Karangmalang Kota Semarang tidak memadai sehingga terlihat banyak tumpukan-tumpakan dus obat di dalamnya. Hal ini menunjukkan bahwa manajemen logistik obat belum berjalan dengan baik.

Penelitian manajemen obat di Puskesmas sebelumnya pernah dilakukan di Puskesmas Lubuk Buaya Kota Padang Tahun 2017 menunjukkan bahwa belum berjalan dengan baik terkait perencanaan dan pengadaan obat masih terdapat 


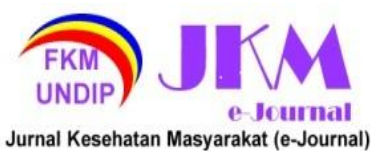

permasalahan pada sistem E-katalog sehingga terjadinya kekosongan obat dan pada penyimpanan obat ukuran gudang tidak memenuhi standar dan obat belum disusun sesuai abjad ${ }^{(3)}$. Penelitian yang lain juga pernah dilakukan di Puskesmas Bulu Lor Kota Semarang menunjukkan bahwa mengalami Out Off Stock (kehabisan stok) serta megalami kekurangan SDM (Sumber Daya Manausia) khususnya pada apoteker sehingga dapat mengganggu kinerja dalam membuat LPLPO (Laporan Pemakaian dan Lembar Permintaan Obat) dan dalam melayani pasien ${ }^{(4)}$.

Berdasarkan penjelasan diatas maka penelitian ini diperlukan untuk mengetahui bagaimana analisis manajemen logistik obat di gudang farmasi Puskesmas Karangmalang Kota Semarang.

\section{METODE PENELITIAN}

JURNAL KESEHATAN MASYARAKAT (e-Journal)

Volume 10, Nomor 1, Januari 2022

ISSN: 2715-5617 / e-ISSN: 2356-3346

http://ejournal3.undip.ac.id/index.php/jkm

Tabel 1. Karakteristik Informan

\begin{tabular}{llll}
\hline \multicolumn{1}{c}{ Subyek penelitian } & Umur & \multicolumn{1}{c}{ Pendidikan } & \multicolumn{1}{c}{ Jabatan } \\
\hline Informan Utama 1 & 27 & S1 Profesi Apoteker & Apoteker \\
Informan Utama 2 & 29 & D3 Farmasi & Tenaga Teknis Apoteker \\
Informan Utama 3 & 47 & D3 Farmasi & Tenaga Teknis Apoteker \\
Informan Triangulasi 1 & 50 & S1 Kedokteran & Kepala Puskesmas \\
Informan Triangulasi 2 & 30 & S1 Kedokteran & Dokter Umum \\
Informan Triangulasi 3 & 53 & S1 Kedokteran Gigi & Dokter Gigi \\
Informan Triangulasi 4 & 34 & S1 Kesehatan Masyarakat & Bendahara \\
Informan Triangulasi 5 & 34 & D3 Farmasi & Asisten Apoteker Penyelia \\
\hline
\end{tabular}

\section{Input}

a. SDM

SDM dalam pengelolaan obat di Farmasi Puskesmas Karangmalang Kota Semarang berjumlah 3 orang yang terdiri dari 1 orang apoteker dan 2 orang Tenaga Teknis Kefarmasian (TTK). Menurut Permenkes RI No 74 Tahun 2016 sudah memenuhi beban kerja dengan rasio kunjungan pasien sebanyak 50 (lima puluh) pasien perhari baik rawat inap maupun rawat jalan. Namun berdasarkan wawancara dengan informan dapat disimpulkan bahwa pelatihan SDM mengenai manajemen pengelolaan obat belum pernah dilakukan. Hal ini dapat mempengaruhi pengetahuan, keterampilan, dan perilaku tenaga farmasi.

b. Anggaran

Dari hasil penelitian, semua subyek penelitian menyatakan bahawa anggaran di Puskesmas Karangmalang berasal dari Anggaran Pendapatan Belanja Daerah (APBD) serta dari Badan Layanan Umum Daerah (BLUD) merupakan dana murni dari pendapatan puskesmas itu sendiri yang didaptkan dari retribusi pasien, kapitasi BPJS, dan klaim rawat inap ataupun klaim persalinan. Anggaran dapat digunakan untuk belanja obat dan bahan medis habis pakai, alat-alat kesehatan,
Jenis penelitian ini menggunakan metode penelitian kualitatif dengan pendekatan deskriptif melalui teknik indepth interview (wawancara mendalam). Penelitian ini dilakukan pada bulan Juni 2021 di Puskesmas Karangmalang Kota Semarang. Pengambilan sampel menggunakan purposive sampling dengan jumlah sampel sebanyak 8 informan yang terdiri dari 3 informan utama dan 5 informan triangulasi. Instrumen yang digunakaan adalah pedoman wawancara, observasi, dan dokumentasi. Data dianalisis dan disajkan dalam bentuk narasi.

\section{HASIL DAN PEMBAHASAN}

\section{Karakteristik Subyek Penelitian}

Subyek penelitian dalam penelitian ini sebanyak 8 informan dengan usia berkisar antara 26-55 tahun. Pendididkan terakhir yang ditempuh yaitu diploma III dan sarjana. Hal ini dapat dilihat pada tabel 1.

pembayaran listrik, pembayaran telepon, dan lainlain.

Hal ini sesuai dengan penelitian yang pernah dilakukan oleh Misi, dkk tahun 2020 bahwa dana yang dialokasikan tidak semua digunakan untuk pembelian obat-obatan tetapi untuk pembelian kebutuhan non medis seperti laboratorium, bahan rontgen, dan bahan medis habis pakai ${ }^{(5)}$.

c. Sarana dan Prasarana

Kegiatan manajemen logistik obat dapat dipengaruhi oleh lengkap atau tidaknya sarana dan prasarana yang dimiliki. Berdasarkan kesimpulan dari semua subyek penelitian bahwa di Gudang Farmasi Puskesmas Karangmalang kegiatan belum terlaksana dengan lancar karena sarana dan prasarana yang dilihat belum cukup atau kurang memadai. Terlihat dari kondisi AC yang rusak dapat menyebabkan suhu di gudang tempat penyimpanan obat tidak terkontrol. Selain itu, kondisi gudang yang dirasa kurang luas sehingga terlihat tumpukan barang-barang yang menyebabkan tidak maksimalnya kerja petugas dalam melakukan penyimpanan obat di gudang farmasi.

Diketahui bahwa luas gudang penyimpanan 2,7 x $4 \mathrm{~m}^{2}$ sedangkan menurut Depkes RI 2010 dalam Pelatihan Manajemen Kefarmasian di 


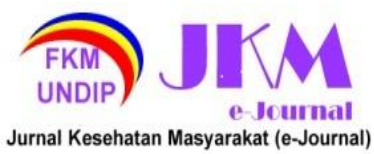

Puskesmas menyebutkan bahwa luas gudang penyimpanan obat minimal $3 \times 4 \mathrm{~m}^{2}$. Hal tersebut tidak sesuai dengan persyaratan minimal luas gudang. Oleh karenanya kurangnya sarana dan prasarana yang ada mengakibatkan kegiatan pengelolaan obat tidak terlaksana dengan baik ${ }^{(3)}$.

d. Prosedur SOP

Dari hasil penelitian, semua subyek penelitian menyatakan bahwa pelaksanaan prosedur yang dibuat dan berlaku di Farmasi Puskesmas Karangmalang sudah dijalankan oleh petugas yang melalukan pengelolaan obat, meskipun dalam pelaksanaan terkadang tidak menerapkan dengan sempurna karena beberapa faktor seperti padatnya kegiatan saat ini sebab melonjaknya kasus COVID19 sehingga pekerjaan harus ditunda pada akhirnya menumpuk. Namun hal tersebut tidak berpengaruh signifikan terhadap manajemen logistik obat. SOP manajemen logistik obat di Farmasi Puskesmas Karangmalang belum sesuai.

Hal ini didapatkan dari hasil observasi yang dilakukan bahwa tidak lengkapnya SOP yang dimiliki dalam proses manajemen logistik obat yang meliputi tahap perencanaan, penerimaan, pengadaan, pencatatan dan pelaporan obat. Dengan begitu adanya ketidaklengkapan prosedur dapat menghambat proses pengelolaan obat terlebih lagi kegiatan yang dilakukan sudah menjadi rutinitas harian ${ }^{(6)}$.

\section{Proses}

a. Perencanaan

Menurut Peraturan Menteri Kesehatan RI

No 74 Tahun 2016 perencanaan kebutuhan obat merupakan kegiatan menentukan jumlah dan jenis obat yang bertujuan untuk meningkatkan keefektifan dan keefesienan dalam pemenuhan kebutuhan obat.

Dari semua pertanyaan mengenai perencanaan obat di Farmasi Puskesmas Karangmalang Kota Semarang dapat diambil kesimpulan bahwa pemilihan jenis obat berdasarkan Formularium Nasional (Fornas) dan disesuaikan dengan jumlah kunjungan pasien. Perhitungan perkiraan jenis obat dengan melihat stok persediaan obat satu bulan ditambah buffer stok. Dalam proses perencanaan penentuan kebutuhan obat menggunakan metode konsumsi dengan memperhatikan pola pemakaian obat paling banyak pada periode sebelumnya. Hal tersebut sesuai dengan pernyataan informan triangulasi bahwa metode konsumsi yang dipakai dalam proses perencanaan.

Penelitian ini sejalan dengan Hiborang, dkk tahun 2016 yang menyebutkan bahwa metode yang digunakan dalam merencanakan kebutuhan obat di puskesmas mengacu pada kebutuhan obat sebelumnya ditambah $10 \%$ pola konsumsi ${ }^{(7)}$.
Namun dalam proses perencanaan obat di Puskesmas Karangmalang permintaan obat tidak terealisasikan $100 \%$. Hal ini dapat menyebabkan obat mengalami jumlah yang berlebihan atau stagnant. Selain itu, kekosongan obat dari Pedagang Besar Farmasi (PBF) yang menyebabkan beberapa obat mengalami stock out. Dengan demikian kejadian obat stagnant dan stock out mengakibatkan kerugian sehingga berepengaruh terhadap pelaksanaan sistem manajemen logistik yang kurang baik ${ }^{(8)}$.

b. Pengadaan

Pengadaan merupakan kegiatan untuk merealisasikan kebutuhan obat yang sudah direncanakan. Tujuan pengadaan yaitu untuk memenuhi kebutuhan obat dan bahan medis habis pakai ${ }^{(9)}$.

Dari semua pertanyaan mengenai pengadaan obat di Farmasi Puskesmas Karangmalang Kota Semarang dapat diambil kesimpulan bahwa proses pengadaan obat dilakukan 1 kali dalam sebulan atau lebih sesuai kebutuhan di Farmasi. Pembelian obat dapat dilakukan dengan 2 cara yaitu pengadaan mandiri dan pengadaan dropping dari Instalasi Farmasi. Namun waktu tunggu obat datang yang lama dapat mengakibatkan terjadinya kekosongan obat dari Instalasi Farmasi Dinas Kesehatan maupun dari PBF (Pedagang Besar Farmasi).

Adanya obat kosong ataupun kadaluwarsa mengakibatkan proses pengelolaan obat tidak berjalan efektif dan efisien sehingga perlu dilakukan evaluasi terhadap manajemen obat ${ }^{(10)}$.

Oleh karena itu untuk meminimalisir kejadian kekosongan obat atau stock out perlu dilakukan evaluasi mengenai perencanaan pengadaan kebutuhan obat pemantauan obat secara berkala serta bekerjasama secara baik dengan distributor sehingga dapat memenuhi kebutuhan obat dengan tepat sesuai kebutuhan.

c. Penerimaan

Penerimaan obat merupakan proses diterimanya obat setelah dilakukan proses pembelian ke distributor maupun Instalasi Farmasi Dinas Kesehatan Kabupaten/Kota sesuai dengan jumlah permintaan ${ }^{(11)}$.

- Dari semua pertanyaan mengenai penerimaan obat di Farmasi Puskesmas Karangmalang Kota Semarang dapat diambil kesimpulan bahwa proses penerimaan obat dimulai dari memeriksa kondisi obat sudah sesuai dengan jumlah, jenis, masa kadaluwarsa, kemudian setelah obat diterima, menginput obat di dalam Sistem Informasi Manajemen Puskesmas (Simpus). Hal ini sesuai dengan Petunjuk Teknis Standar Pelayanan Kefarmasian tahun 2019.

Namun dalam proses penerimaan terdapat obat yang expired masa kadaluwarsanya pendek. 


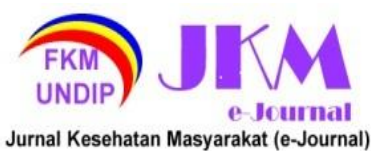

Hal ini mengakibatkan obat cepat kadaluwarsa. Penyebab obat kadaluwarsa dipengaruhi oleh adanya perubahan pola peresepan dan kurangnya skrinning saat penerimaan obat sehigga didapatkan obat yang diterima memiliki Expired Date (ED) pendek ${ }^{(12)}$.

Oleh karena itu untuk meminimalisir kejadian obat kadaluwarsa dilakukan dengan cara penghabisan ataupun mendahulukan pengeluaran obat yang akan mendekati ED.

d. Penyimpanan

Penyimpanan merupakan suatu kegiatan menyimpan dengan cara menempatkan obat yang diterima pada tempat yang aman, terhindar dari kerusakan fisik atau kehilangan supaya mutu obat tetap terjamin ${ }^{(11)}$.

Dari semua pertanyaan mengenai penyimpanan obat di Gudang Farmasi Puskesmas Karangmalang Kota Semarang dapat diambil kesimpulan bahwa proses penyimpanan sudah dilaksanakan sesuai Standar Operasional Prosedur (SOP) dengan menerapkan metode First In First Out (FIFO) atau First Expired Firs Out (FEFO) yang disusun berdasarkan alfabetis.

Namun, dalam pelaksanaannya belum berjalan maksimal karena gudang yang belum memadai untuk melakukan penyimpanan dengan luas 2,7 x $4 \mathrm{~m}^{2}$ sehingga masih telihat banyak tumpukan-tumpukan kardus di dalam gudang. Hal ini tidak sesuai Materi Pelatihan Manajemen Kefarmasian di Puskesmas yang menyebutkan bahwa persyaratan luas gudang minimal $3 \times 4 \mathrm{~m}^{2}$ atau disesuaikan dengan jumlah obat yang disimpan (13).

Menurut penelitian yang pernah dilakukan oleh Nurniati, dkk tahun 2016 standar penyimpanan obat harus memiliki pendingin ruangan, penyimpanan obat biasa dan vaksin harus terpisah, memiliki lemari penyimpanan yang cukup serta luas ruangan yang memadai ${ }^{(14)}$.

e. Pendistribusian

Distribusi adalah kegiatan penyaluran obat ke sub-sub unit pelayanan kesehatan secara merata dan teratur supaya tersedianya kebutuhan obat sesuai dengan tepat waktu, tepat jumlah, dan tepat jenisnya yang ada di sub unit pelayanan kesehatan (11)

Dari semua pertanyaan mengenai pendistribusian obat di Gudang Farmasi Puskesmas Karangmalang Kota Semarang dapat diambil kesimpulan bahwa proses pendistribusian obat dilakukan dengan 2 cara yaitu pertama, distribusi di dalam gedung Puskesmas yang meliputi rawat inap dan rawat jalan dilakukan dengan cara floor stock atau pemberian obat sesuai resep yang diterima. Kedua, distribusi di luar gedung Puskesmas yang meliputi posyandu lansia dan posyandu remaja. Sebelum dilakukan penyerahan obat, petugas farmasi harus mengecek sisa stok obat kemudian mencatat obat yang akan dikeluarkan dan disertai tanda tangan oleh pengelola obat. Hal ini sesuai dengan Petunjuk Tenis Standar Pelayanan Kefarmasian tahun 2019.

Namun, dalam pelaksanaannya masih kurang baik karena obat yang diminta terkadang datang telambat karena masih dalam pemesanan atau bahkan kosong. Banyak sedikitnya jumlah permintaan obat dapat mempengaruhi proses pendistribusian obat di Farmasi Puskesmas Karangmalang. Sebab pendistribusian dapat dilakukan apabila ketersediaan obat memenuhi di gudang farmasi namun, pendistribusian tidak dapat dilakukan apabila ketersediaan obat di gudang farmasi tidak memenuhi.

Sehingga untuk menghindari kejadian tersebut sebaiknya pihak farmasi lebih meningkatkan pemantauan obat secara berkala supaya dapat meminimalisir adanya obat kosong.

f. Pengendalian

Pengendalian persediaan merupakan suatu kegiatan untuk memastikan agar tidak terjadi kekosongan ataupun kelebihan obat di unit pelayanan kesehatan ${ }^{(11)}$.

Dari semua pertanyaan mengenai pengendalian obat di Gudang Farmasi Puskesmas Karangmalang Kota Semarang dapat diambil kesimpulan bahwa pengendalian obat dilakukan dengan cara memisahkan obat yang kadaluwarsa/rusak, melaporkan ke Instalasi Farmasi Dinas Kesehatan Kota Semarang, setelah mendapatkan jadwal pemusnahan membuat laporan berita acara dan menyerahkan obat jenis tablet ke Instalasi Farmasi sebab puskesmas tidak mempunyai alat untuk memusnahkan obat jenis tablet.

Namun selain jenis tablet dapat dimusnahkan oleh pihak Puskesmas sendiri. Pemusnahan obat kadaluwarsa/rusak di Farmasi Puskesmas Karangmalang sudah dilakukan dengan rutin setiap 3 bulan sekali.

Hal tersebut sesuai dengan pernyataan informan triangulasi bahwa pemusnahan obat dilakukan 4 kali dalam setahun dengan ketentuan obat jenis tablet tidak dimusnahkan sendiri melainkan dimusnahkan oleh pihak ketiga karena, Puskesmas tidak memiliki alat yang digunakan untuk memusnahkan jenis tablet tersebut.

g. Pencatatan dan Pelaporan

Pencatatan dan Pelaporan merupakan kegiatan keseluruhan dalam pengelolaan obat yang diterima, disimpan, didistribusikan, dan digunakan dalam Puskesmas atau unit pelayanan lainnya ${ }^{(11)}$.

Dari semua pertanyaan mengenai pencatatan dan pelaporan obat di Gudang Farmasi Puskesmas Karangmalang Kota Semarang dapat diambil kesimpulan bahwa petugas farmasi 


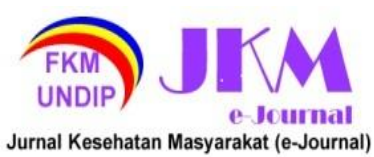

melakukan pencatatan berupa LPLPO (Laporan Pemakaian dan Lembar Permintaan Obat) berdasarkan jumlah obat yang diterima, jumlah pengeluaran obat, dan sisa stok obat. Kemudian dilaporkan ke Instalasi Farmasi Dinas Kesehatan Kota Semarang setiap sebulan sekali.

Dalam pelaksanaan pencatatan dan pelaporan obat ditemukannya beberapa jenis item obat berlebih karena jarang digunakan atau diresepkan sehingga kemungkinan obat tersebut mengalami kerusakan atau kadaluwarsa.

Selain itu masalah lain yang ditemukan yaitu sering terjadinya obat hilang di Instalasi Gawat Darurat (IGD) Puskesmas Karangmalang karena tidak ada petugas farmasi yang berjaga pada jam malam. Hal tersebut belum sesuai dengan Permenkes Nomor 74 Tahun 2016 yang menyebutkan bahwa pengelolaan obat yang baik dapat mengurangi terjadinya obat rusak, hilang, dan kadaluwarsa sehingga dana alokasi yang tersedia untuk pelayanan kesehatan dapat digunakan lebih efektif dan efisien.

\section{Output}

Menurut Permenkes No 74 Tahun 2016 salah stau tujuan dari pengelolaan persediaan obat adalah menjamin ketersediaan dan keterjangkauan sediaan farmasi dan bahan medis habis pakai yang efesien, efektif, rasional, dan bermutu.

berdasarkan hasil dari subyek penelitian menyatakan bahwa secara garis besar ketersediaan obat di Farmasi Puskesmas Karangmalang sudah sesuai kebutuhan, akan tetapi terdapat beberapa obat terkadang tidak tersedia yang disebabkan stok terbatas dan kekosongan dari distributor.

Subyek penelitian lainnya juga menyatakan bahwa di Farmasi Puskesmas Karangmalang Kota Semarang masih ada obat yang mengalami kekosongan, kadaluwarsa bahkan obat hilang. Adapun upaya yang dilakukan pihak Farmasi Puskesmas Karangmalang Kota Semarang dalam mengatasi terjadinya kekosongan obat yaitu dengan mencarikan obat ke Pedagang Besar Farmasi (PBF) lain.

Namun apabila terjadinya kekosongan semua di distributor manapun dapat digantikan dengan obat yang kandungannya sama sesuai dengan perintah dokter. Dengan masih adanya obat yang mengalami kekosongan, kadaluwarsa, dan hilang maka dapat dikatakan bahwa input terhadap pelaksanaan prosedur kerja yang kurang maksimal, sarana prasarana yang kurang memadai seperti di gudang penyimpanan obat.

\section{KESIMPULAN}

1) Dalam aspek input, SDM di Farmasi Puskesmas Karangmalang semua belum pernah dilakukan pelatihan mengenai pengelolaan obat. Sarana dan prasarana di gudang farmasi Puskesmas Karangmalang kurang memadai. Selain itu, adanya ketidaklengkapan SOP dalam manajemen logistik obat di farmasi Puskesmas Karangmalang.

2) Dalam aspek proses, pada proses perencanaan dan pengadaan obat belum berjalan baik karena masih sering terjadi kekosongan dari Pedagang Besar Farmasi (PBF). Penyimpanan obat belum berjalan dengan baik karena kondisi gudang yang berukuran kecil sehingga menyebbkan banyak tumpukan-tumpukan kardus yang berisi obat. Sedangkan pencatatan dan pelaporan obat dalam pencatatannya sering terjadi obat hilang di IGD karena jarang dilakukan peresepan.

3) Dalam aspek output, ketersediaan kebutuhan obat di Farmasi Puskesmas Karangmalang sudah sesuai kebutuhan, akan tetapi pelaksanaan manajemen logistik obat di farmasi Puskesmas Karangmalang masih belum efektif dan efisien karena masih terdapat obat yang mengalami kekosongan, kadaluwarsa/rusak, bahkan obat hilang.

\section{SARAN}

1) Bagi Dinas Kesehatan, diharapkan dapat meningkatkan monitoring dan evaluasi terhadap pelaksanaan manajemen logistik obat di seluruh puskesmas. Serta dapat memberikan pelatihan kepada para apoteker untuk meningkatkan kemampuan dan pengetahuan di bidang farmasi

2) Bagi Puskesmas Karangmalang, diharapkan juga dapat meningkatkan monitoring dan evaluasi sendiri terhadap kegiatan pengelolaan obat di farmasi dan memberikan pelatihan kepada para apoteker. Serta lebih memperhatikan sarana dan prasarana di gudang farmasi yang kurang memadai khusunya untuk gudang farmasi segera direnovasi sesuai minimal standar luas gudang dan memperbaiki kondisi AC yang sering rusak agar kegiatan pengelolaan obat dapat terlaksana secara efektif dan efisein.

3) Bagi peneliti lain, diharapkan dapat mengembangkan penelitian lebih lanjut mengenai manajemen logistik obat di gudang farmasi Puskesmas Karangmalang Kota Semarang.

\section{DAFTAR PUSTAKA}

1. Sarlin Djuna dkk. Studi Manajemen Pengelolaan Obat di Puskesmas Labakkang Kabupaten Pangkep. 2014;1-13.

2. Kemenkes RI. Laporan Kinerja Direktorat Jenderal kefarmasian dan Alat Kesehatan. Jakarta: Kementerian Kesehatan RI; 2020.

3. Sulrieni IN, Rozalina S. Analisis 


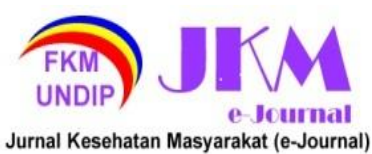

Manajemen Logistik Obat di Puskesmas Lubuk Buaya Kota Padang. J Kesehat Saintika Meditory. 2019;1(2):125-35.

4. Khairuzzaman MQ. Gambaran Faktor yang Melatarbelakangi Perencanaan Obat di Puskesmas Bulu Lor Kota Semarang Tahun 2015. 2016;4(1):64-75.

5. Misi MA, Arifin MA, Palutturi S, Indrar, Thaha RM, Naiem F, et al. Evaluation of Drug Planning and Procurement at the Pharmacy Installation of Regional General Hospital Dr. M. Haulussy Ambon. MedicoLegal Updat. 2020;20(4):1150-6.

6. Giyana F. Analisis Sistem Pengelolaan Rekam Medis Rawat Inap Rumah Sakit Umum Daerah Kota Semarang. J Kebijak Kesehat Indones. 2012;1(2):48-61.

7. Hiborang SS, Maramis FRR, Kandou GD. Gambaran Pelaksanaan Pengelolaan Obat di Puskesmas Paniki Bawah Kota Manado Tahun 2016.

8. Hadidah IS, Rochmah TN. Faktor Penyebab Kejadian Stagnant Dan Stockout Di Instalasi Farmasi Upt Rumah Sakit Mata Masyarakat Jawa Timur. J Manaj Kesehat Yayasan RSDr Soetomo. 2016;2(2):110-7.

9. Permenkes RI. Peraturan Menteri Kesehatan Republik Indonesia Nomor 44 Tahun 2016 tentang Pedoman Manajemen Puskesmas. Jakarta: Kementerian Kesehatan Republik Indonesia; 2016.

10. Handayany GN, Fathurrahmi. Management of Drug Logistics at Pharmacy Installation Dr. Wahidin Sudirohusodo Makassar Hospital. Int J Pharm Res. 2020;13(1):4915.

11. Permenkes RI. Peraturan Menteri Kesehatan Republik Indonesia Nomor 74 Tahun 2016 tentang Standar Pelayanan Kefarmasian di Puskesmas. Jakarta: Kementerian Kesehatan Republik Indonesia; 2016.

12. Khairani RN, Latifah E, Nila Septianingrum NMA. Evaluasi Obat Kadaluwarsa, Obat Rusak dan Stok Mati di Puskesmas Wilayah Magelang. J Farm Dan Ilmu Kefarmasian Indones. 2021;8(1):91.

13. JICA \& Kemenkes RI. Materi Pelatihan Manajemen Kefarmasian di Puskesmas. Jakarta: Kemeterian Kesehatan. Direktorat Jenderal Bina Kefarmasian dan Alat Kesehatan; 2010.

14. Nurniati L, Lestari H, Lisnawaty. Studi Pengelolaan Obat di Puskesmas Buranga Kabupaten Wakatobi Tahun 2016. 2016;19. 